University of Nebraska - Lincoln

DigitalCommons@University of Nebraska - Lincoln

1995

\title{
Syrphids as natural enemies of cereal aphids in Germany: Aspects of their biology and efficacy in different years and regions
}

Brigitte Tenhumberg

University of Nebraska - Lincoln, btenhumberg2@unl.edu

Hans-Michael Poehling

University of Göttingen, poehling@ipp.uni-hannover.de

Follow this and additional works at: https://digitalcommons.unl.edu/bioscifacpub

Part of the Life Sciences Commons

Tenhumberg, Brigitte and Poehling, Hans-Michael, "Syrphids as natural enemies of cereal aphids in Germany: Aspects of their biology and efficacy in different years and regions" (1995). Faculty Publications in the Biological Sciences. 206.

https://digitalcommons.unl.edu/bioscifacpub/206

This Article is brought to you for free and open access by the Papers in the Biological Sciences at DigitalCommons@University of Nebraska - Lincoln. It has been accepted for inclusion in Faculty Publications in the Biological Sciences by an authorized administrator of DigitalCommons@University of Nebraska - Lincoln. 


\title{
Syrphids as natural enemies of cereal aphids in Germany: Aspects of their biology and efficacy in different years and regions
}

\author{
Brigitte Tenhumberg \\ Department of Biological Sciences, Simon Fraser University, Burnaby, B.C. V5A 1S6, Canada (Corresponding author) \\ Hans-Michael Poehling \\ Department of Entomology, Institute for Plant Pathology, University of Göttingen, Grisebachstrasse 6, 37070 Göttingen, \\ Germany (Present address: Department of Entomology, Institute for Plant Pathology and Plant Protection, \\ University of Hannover, Herrenhäuser Str, 2, 30419 Hannover, Germany)
}

\begin{abstract}
An evaluation was made of the influence of aphidophagous syrphid larvae on the population dynamics of cereal aphids in winter wheat in Germany, using both field records and published information. The peak density of aphid populations was significantly dependent on aphid abundance at the time syrphid larvae became active, a fact indicating the high predation potential of the beneficials as well as the importance of synchronization. The level of aphid infestation was generally lower in southern than in northern Germany. This difference may result from syrphid larvae being 2-3 weeks earlier in southern Germany, when aphid numbers were only half those found in northern Germany.
\end{abstract}

Keywords: biological control, synchronization, syrphids

\section{Introduction}

During the progradation phase of an aphid infestation in winter wheat, stenophagous predators (Syrphidae, Coccinellidae, and Chrysopidae) may significantly reduce the population growth rate of the pest. Except in eastern Germany, where syrphid densities are generally very low (Wetzel et al., 1981 ), syrphids represent approximately $80 \%$ of all stenophagous predators elsewhere in Germany (Groeger, 1992; Tenhumberg, 1992). To understand variations in the influence syrphids have in different years and regions, the authors analyzed various aspects of their biology that may contribute to their predation efficacy. This paper reports on the interactions between aphids and syrphids in southern and northern Germany. The data of Hasken (1989), Hilbeck (1989), Groeger (1992), Hasken and Poehling (1993), Schier (1988) and B. Niehoff (unpublished data, 1993) are discussed.

\section{Materials and methods}

For the analysis, cereal fields in Lower Saxony were surveyed between 1984 and 1990. Every 3 days, aphid and syrphid densities were estimated by counting all individuals on 100 plants per plot. To determine syrphid densities more precisely, during 1988-1990, all wheat shoots growing in a $10 \mathrm{~cm}^{2}$ area, 12 areas per plot, were cut and transferred to the laboratory where they were examined for pre-imaginal stages, which are often overlooked in field counts. Species composition was determined by collecting syrphid larvae in the field. The larvae were reared under controlled conditions $\left(20^{\circ} \mathrm{C}, 60-70 \%\right.$ relative humidity) and any emerging adults were identified.

To estimate the potential predation efficiency, 3-day-old larvae were placed singly into Petri dishes ( $5 \mathrm{~cm}$ in diameter). The larvae were fed ad libitum with third-instar larvae of Metopolophium dirhodum 
Walker. The number of aphids consumed by each larva during successive $24 \mathrm{~h}$ intervals were counted. In this way the maximum voracity of syrphid larvae was investigated at four different temperatures (14, 17,20 , and $\left.22^{\circ} \mathrm{C}\right)$.

\section{Results and discussion}

Six different species of Syrphidae from larvae collected in winter wheat were reared (Table 1). Episyrphus balteatus de Geer was the most abundant species, constituting over $90 \%$ of all larvae found. For this reason, the evaluation of overall predatory efficiency was simplified by assuming that E. balteatus was characteristic of other species as well.

The potential voracity of E. balteatus larvae is very sensitive to changing environmental conditions. Depending on the temperature, a single larva may consume between 660 and 1140 third-instar aphids during larval development (Figure 1). However, the efficiency of predators is determined also by the handling time (Holling, 1959). Thus the estimation of consumption rates from laboratory data may lead to an overestimation of the influence of predators on the pest population dynamics. A more appropriate method is to calculate predator efficiency under "semi-field" conditions. In such experiments, the food intake can be estimated from the Holling Type III-function, which takes into account all components of handling time as well as satiation. For E. balteatus, the function is

$$
V_{N}=\left(396 \times N^{2}\right) /\left(N^{2}+246^{2}\right)
$$

where $V_{N}$ indicates the number of aphids consumed by one larva during development and $N$ measures prey density. This formula suggests that syrphid larvae adapt their feeding rates to varying food supplies, with a maximum consumption of 396 aphids

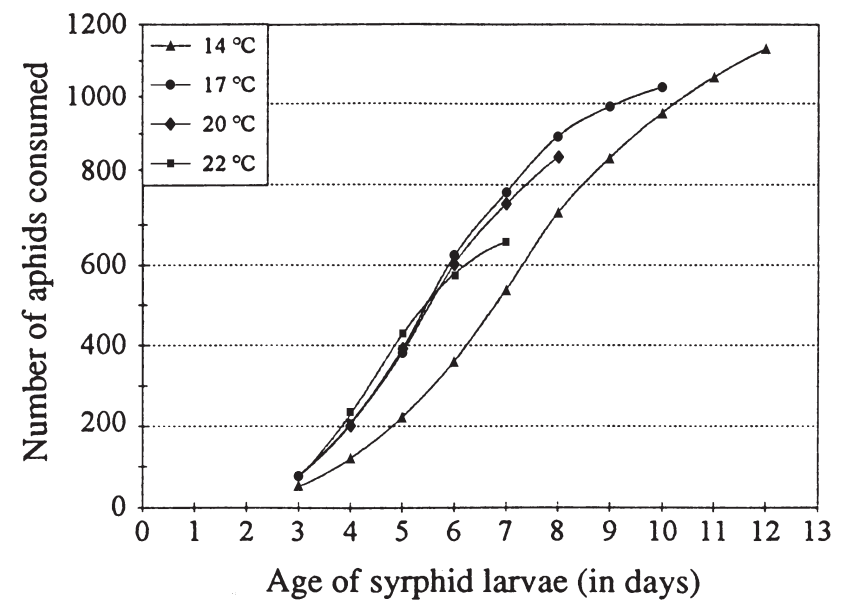

Figure 1. Cumulative voracity of syrphid larvae in relation to temperature (symbols indicate means ).

per individual (for the derivation of Equation (1) see Tenhumberg, 1994).

Syrphid larvae feed very little during the first two instars and, again, 1-2 days before pupation; at average summer temperatures nearly $70 \%$ of the total food is consumed between days 7-10 of larval life. During peak aphid densities, syrphid populations consisted mainly of individuals of peak voracity. Because younger syrphid larvae may not find sufficient food to complete their larval development during this period, females stop laying eggs in older aphid colonies (Kan, 1988) or in the presence of thirdinstar larvae (Hemptinne et al., 1993). Thus the food intake of one third-instar larva is approximately 90 aphids per day $((396 \times 0.7) / 3=90.2)$ during maximum aphid abundance. At syrphid densities between 0.02 and 0.22 larvae per shoot, each larva consumes 1.8-19.8 aphids per day (Table 2). On that basis, the syrphids are expected to consume, on average, $50 \%$ of the aphids present.

Table 1. Species composition of syrphid larvae occurring in winter wheat in 1988-1990

\begin{tabular}{|c|c|c|c|c|c|c|}
\hline \multirow[t]{2}{*}{ Species } & \multicolumn{2}{|l|}{1988} & \multicolumn{2}{|l|}{1989} & \multicolumn{2}{|l|}{1990} \\
\hline & $\%$ & $n$ & $\%$ & $n$ & $\%$ & $n$ \\
\hline Episyrphus balteatus (De G. ) & 93.8 & 275 & 91.0 & 471 & 96.0 & 696 \\
\hline Eupeodes corollae (Fabr. ) & 1.0 & 3 & 3.0 & 16 & 0.8 & 6 \\
\hline Eupeodes lundbeckii (Soot-Ryen) & 0.0 & 0 & 0.0 & 0 & 0.1 & 1 \\
\hline Melanostoma mellinum (L. ) & 0.0 & 0 & 0.0 & 0 & 0.4 & 3 \\
\hline Scaeva pyrastri (L. ) & 3.1 & 9 & 6.0 & 30 & 1.0 & 7 \\
\hline Sphaerophoria scripta (L. ) & 2.1 & 6 & 0.2 & 1 & 1.7 & 12 \\
\hline
\end{tabular}


Table 2. Comparison of abundance of cereal aphids and syrphids during peak infestation of the pest and the voracity of the beneficials at that time. Values estimated from Holling III-function (see Equation (1) ) between northern and southern Germany.

\begin{tabular}{|c|c|c|c|c|c|c|c|c|}
\hline \multirow[t]{3}{*}{ Year } & \multirow{2}{*}{\multicolumn{2}{|c|}{$\begin{array}{l}\text { Aphid density } \\
\text { per shoot }\end{array}$}} & \multirow{2}{*}{\multicolumn{2}{|c|}{$\begin{array}{l}\text { Syrphid density } \\
\text { per shoot }\end{array}$}} & \multicolumn{4}{|c|}{ Syrphid voracity during aphid maximum } \\
\hline & & & & & Numb & hids & $\%$ of ap & aximum \\
\hline & North & South & North & South & North & South & North & South \\
\hline 1984 & - & $5.4^{7}$ & - & 0.03 & - & 2.7 & - & 50 \\
\hline 1985 & - & $8.5^{7}$ & - & 0.03 & - & 2.7 & - & 32 \\
\hline 1986 & - & $3.3^{7}$ & - & 0.02 & - & 1.8 & - & 55 \\
\hline 1987 & $7.1^{3}$ & $14.5^{5}$ & 0.06 & 0.00 & 5.4 & 0.0 & 77 & 0 \\
\hline 1988 & $56.4^{1}$ & $13.7^{2}$ & 0.10 & 0.08 & 8.7 & 7.2 & 15 & 53 \\
\hline 1988 & - & $13.8^{2}$ & - & 0.06 & - & 5.4 & - & 39 \\
\hline 1989 & $18.3^{1}$ & $13.1^{2}$ & 0.04 & 0.05 & 3.3 & 4.5 & 18 & - \\
\hline 1990 & $8.9^{1}$ & $36.2^{2}$ & 0.05 & 0.16 & 4.3 & 14.4 & 49 & - \\
\hline 1990 & $2.6^{1}$ & - & 0.02 & - & 2.1 & - & 80 & - \\
\hline 1991 & $9.5^{4}$ & - & 0.14 & - & 12.6 & - & 133 & - \\
\hline 1991 & $16.6^{6}$ & - & 0.22 & - & 19.8 & - & 119 & - \\
\hline 1992 & $171.0^{6}$ & - & 0.03 & - & 2.3 & - & 1 & - \\
\hline
\end{tabular}

Source of data: 1. own observations; 2. Groeger (1992); 3. Hasken (1989); 4. Hasken and Poehling (1993); 5. Hilbeck (1989); 6. B. Niehoff (unpublished data, 1993); 7. Schier (1988).

The impact of natural enemies is dependent on the relationship between the rate of increase of the pest population and the feeding rate of the beneficials (Bombosch, 1963). Because aphid populations grow exponentially, syrphid larvae should achieve a greater impact on aphid population if they occur early in cereal fields. If spring weather is favorable for aphid population growth, a time lag of a few days only could be responsible for a failure of biological control.

Syrphids are well adapted to early population increase of aphids. Females deposit their eggs in or near aphid colonies, orienting themselves to the odor of aphid honeydew or cornicle secretions. From the start of oviposition, the number of eggs laid is normally positively correlated with aphid abundance (Table 3). Because the eggs hatch after only 3 days, the predatory larvae occur soon after the beginning of oviposition. Oviposition occurs at low infestation rates, e.g. only 0.2 aphids per shoot (Chambers, 1991). Thus, if an autochthonous population occurs in a given area a precise synchronization would be expected. Nevertheless, in northern Germany, the first larvae were found only at a density of seven aphids per shoot (average of 6 years) (Table 4). In contrast, in southern Germany, the first syrphid larvae were recorded at half that density, a fact which may explain the lower peak abundance of aphids there.
Apart from aphid density, the egg-laying behavior of females is influenced by other factors including temperature (Ankersmit et al., 1986), humidity (Wahbi, 1967), light, aphid species, and plant density (Chandler, 1968). However, any variations in these factors cannot account entirely for the regular difference between northern and southern Germany.

The authors suggest that the timing of syrphid migration into cereals is most likely the primary cause for such a difference. Episyrphus balteatus overwinters as mated females (Gatter and Schmid, 1990). At the end of March, the first eggs are found on the primary hosts of aphids, i.e. in hedges, forest boundaries or house gardens (Zwölfer et al., 1984; Schier, 1988). Ankersmit et al. (1986) reported that the average generation time is approximately 45 days in spring. Thus

Table 3. Relationship between the number of eggs laid by syrphid females and aphid density in 1988-1990. In 1990 there were two oviposition periods: May 19-June 6 (Period 1 ) and June 19-July 4 ( Period 2).

\begin{tabular}{llll}
\hline Year & Model & $r$ & Probability level \\
\hline 1988 & $\mathrm{y}=0.013+0.0017 x$ & 0.76 & $* *$ \\
1989 & $\mathrm{y}=0.005+0.0076 x$ & 0.81 & $* * *$ \\
$1990($ Period 1) & $\mathrm{y}=0.243+0.056 x$ & 0.5 & $*$ \\
$1990($ Period 2) & $\mathrm{y}=0.095+0.0096 x$ & 0.64 & $* * *$ \\
\hline
\end{tabular}

* $P \leq 0.05 ;{ }^{* *} P \leq 0.01$; *** $P \leq 0.001$ 
Table 4. Comparison of aphid abundance during peak density and during first occurrence of syrphid larvae in northern and southern Germany.

\begin{tabular}{|c|c|c|c|c|c|}
\hline \multirow[t]{3}{*}{ Year } & \multicolumn{4}{|c|}{ No aphids per shoot at } & \multirow{3}{*}{$\begin{array}{c}\text { Time } \\
\text { lag } \\
\text { in days }\end{array}$} \\
\hline & \multicolumn{2}{|c|}{ Peak density } & \multicolumn{2}{|c|}{ First larval occurrence } & \\
\hline & North & South & North & South & \\
\hline 1984 & $10^{1}$ & $5^{3}$ & 1.5 & 1.5 & 22 \\
\hline 1985 & $59^{1}$ & $9^{3}$ & 13.7 & 0.8 & 23 \\
\hline 1986 & $6^{1}$ & $3^{3}$ & 2.3 & 0.1 & 16 \\
\hline 1988 & $56^{1}$ & $14^{2}$ & 11.8 & 4.0 & 13 \\
\hline 1989 & $18^{1}$ & $13^{2}$ & 14.4 & 0.5 & 25 \\
\hline 1990 & $3^{1}$ & $36^{2}$ & 0.4 & $1.0^{\mathrm{a}}$ & 3 \\
\hline 1990 & $9^{1}$ & $36^{2}$ & 5.0 & $1.0^{\mathrm{a}}$ & 3 \\
\hline
\end{tabular}

a. Higher densities of syrphid larvae (0.08 per shoot) were observed 19 days after first larval occurrence. At this time the abundance of the pest was 15 aphids per shoot.

Source of data: 1. own observations; 2. Groeger (1992); 3. Schier (1988).

the first eggs of the second generation developing in cereals would not be expected before the second half of May. As visual inspections did not reveal the presence of aphids before the end of May, or even the beginning of June, syrphid eggs probably were laid just at the beginning of the build-up of aphid population. Accordingly the period of oviposition in southern Germany apparently begins as soon as the threshold for oviposition ( 0.2 aphids per shoot) is reached. In the north, a precise synchronization occurred in only 3 of 10 years. This suggests that, in accordance with aphid densities, syrphids migrated earlier into winter wheat in the south in all 6 years ( 1983-1986, 1988-1990), but were late in the north, except in 1990 (Table 4).

The observed time lag in syrphid immigration into wheat fields between northern and southern Germany could be explained by long distance migration or alternatively by different environmental conditions. It is probable that syrphid eggs found in cereal crops are not solely from autochthonous populations. Aphidophagous syrphids migrate over long distances, especially species such as E. balteatus (Gatter and Schmid, 1990). In autumn, these species fly to suitable hibernating sites in southern Europe or northern Africa and return to the north when flowering plants and aphids become available again in spring. Ankersmit et al. (1986) and Suter and Keller (1977) reported that, in the Netherlands and Switzerland, migrating individuals make up a very high percentage of the total syrphid pop- ulation in June. If this is also true for Germany, the occurrence of syrphids in cereals in northern Germany 2-3 weeks later than in the south would be in accordance with the time adults need to cover the distance of approximately $600 \mathrm{~km}$ between these regions.

However, the later occurrence of syrphid larvae in northern Germany may also reflect different environmental conditions, such as increased habitat diversity or warmer spring conditions in southern Germany which favor syrphid development. The availability of hibernation sites is complemented by early flowering shrubs, which supply pollen and nectar for the adults. Therefore, early development on the primary host of cereal aphids may be of utmost importance for the yearly build-up of autochthonous populations. Furthermore, as a result of higher spring temperatures in southern Germany, plants may flower earlier. Thus, pollen needed for the maturation of the ovarioles is available earlier to females. Together with a higher developmental rate in the subsequent pre-imaginal stages, the second generation thus may occur earlier in cereals. However, even in years with similar climatic conditions, a time lag between larval occurrence in northern and southern Germany may occur (Poehling et al., 1991).

Acknowledgments - Thanks are expressed to Manfred Mackauer for comments on an earlier draft of the manuscript and Berthold Niehoff for permission to use unpublished data. This research was supported by the German Research Foundation.

\section{References}

Ankersmit, G. W., Dijkman, H., Keuning, N. J., Mertens, H., Sins, A., and Tacoma, H. M., 1986. Episyrphus balteatus as a predator of the aphid Sitobion avenae on winter wheat. Entomol. Exp. Appl., 42:271-277.

Bombosch, S., 1963. Untersuchungen zur Vermehrung von Aphis fabae Scop. in Samenrübenbeständen unter besonderer Berücksichtigung von Schwebfliegen (Diptera: Syrphidae). Z. Angew. Entomol., 52:105-141.

Chambers, R. J., 1991. Oviposition by aphidophagous hoverflies (Diptera: Syrphidae) in relation to aphid density and distribution in winter wheat. In: L. Polgar, R. J. Chambers, A.F.G. Dixon, and I. Hodek (eds.), Behaviour and Impact of Aphidophaga. SPB Academic, Den Haag, pp. 115-121.

Chandler, A.E.F., 1968. Some factors influencing the occurrence and site of oviposition by aphidophagous Syrphidae (Diptera). Ann. Appl. Biol., 61:435-446. 
Gatter, W. and Schmid, U., 1990. Wanderungen der Schwebfliegen (Diptera, Syrphidae) am Randecker Maar. Spixiana, Suppl. 15: 44-59.

Groeger, U., 1992. Untersuchungen zur Regulation von Getreideblattlauspopulationen unter dem Einfluss der Landschaftsstraktur. Agrarökologie, 6:1-169.

Hasken, K.-H., 1989. Vergleichende Untersuchungen zur Ermittlung der Wirkung von natürlichen Feinden auf die Populationsentwicklung der Getreideblattläuse im Winterweizen. Diplomarbeit, University of Göttingen.

Hasken, K.-H. and Poehling, H.-M., 1993. Some effects of low input agriculture on cereal aphids and aphid specific predators in winter wheat. Bull. IOBC/WRPS, 17(4): 137-147.

Hemptinne, J.-L., Doucet, J.-L., and Gaspar, C., 1993. How do ladybirds and syrphids respond to aphids in the field. Bull. IOBC/WRPS, 17(4): 101-111.

Hilbeck, A., 1989. Untersuchungen zur Populationsdynamik von Getreideblattläusen und Blattlausprädatoren an der Traubenkirsche (Frühjahrswirt) und im Winterweizen (Sommerwirt) im Raum Hohenheim. Diplomarbeit, University of Hohenheim.

Holling, C.S., 1959. Some characteristics of simple types of predation and parasitism. Can. Entomol., 91:385-389.

Kan, E., 1988. Assessment of aphid colonies by hoverflies. I. Maple aphids and Episyrphus balteatus (de Geer) (Diptera: Syrphidae). J. Ethol., 6:39-48.

Poehling, H.-M., Tenhumberg, B., and Groeger, U., 1991. Different pattern of cereal aphid population dynamics in northern (Hannover-Göttingen) and southern areas of West Germany. Bull. IOBC/WRPS, 14(4): 1-12.
Schier, A., 1988. Untersuchungen zur Populationsdynamik der Getreideblattläuse unter besonderer Berücksichtigung ihrer natürlichen Gegenspieler. Ph.D. Thesis, University of Hohenheim.

Suter, H., and Keller, S., 1977. Ökologische Untersuchungen an feldbaulich wichtigen Blattlausarten als Grundlage für eine Befallsprognose. Z. Angew. Entomol., 83:371-393.

Tenhumberg, B., 1992. Untersuchungen zur Populationsdynamik von Syrphiden in Winterweizenbeständen und Quantifizierung ihrer Bedeutung als Antagonisten von Getreideblattläusen. Ph.D. Thesis, University of Göttingen.

Tenhumberg, B., 1994. Estimating the predatory efficiency of Episyrphus balteatus (Diptera: Syrphidae) in cereal fields (submitted).

Wahbi, A. A., 1967. Untersuchungen über den Einfluss der Temperatur und der relativen Luftfeuchtigkeit auf das Frassvermögen von Syrphidenlarven (Diptera, Syrphidae). Ph.D. Thesis, University of Göttingen.

Wetzel, Th., Ghanim, A.E.B., and Freier, B., 1981. Zur Bedeutung yon Prädatoren und Parasiten für die Überwachung und Bekämpfung von Blattläusen in Getreidebeständen. Nachrichtenbl. Pflanzenschutzdienst DDR, 35:239-244.

Zwölfer, H., Bauer, G., Heusinger, G., and Stechmann, D.-H., 1984. Die tierökologische Bedeutung und Bewertung von Hecken. Beiheft 3/2 zu den Berichten der Akademie für Naturschutz und Landschaftspflege, Laufen. 